\title{
Evaluation of the incidence of aortic aneurysms in patients with and without diabetes in Poland in 2012 based on the database of the National Health Fund
}

Waldemar Wierzba ${ }^{1}$, Jaroslaw Pinkas², Waldemar Karnafel ${ }^{3}$, Piotr Dziemidok ${ }^{4}$, Arkadiusz Jawień ${ }^{5}$, Andrzej Śliwczynski ${ }^{6}$

\author{
${ }^{1}$ Department of Public Health, University of Humanities and Economics, Lodz, Poland \\ ${ }^{2}$ Department of Health Care, Center of Postgraduate Medical Education, Warsaw, \\ Poland \\ ${ }^{3}$ Department of Diabetology, Medical University of Warsaw, Warsaw, Poland \\ ${ }^{4}$ Department of Diabetology, Institute of Rural Health, Lublin, Poland \\ ${ }^{5}$ Department of Vascular Surgery and Angiology, Collegium Medicum in Bydgoszcz, \\ Nicolaus Copernicus University in Torun, Poland \\ ${ }^{6}$ Division of Quality Services, Procedures and Medical Standards, Medical University \\ of Lodz, Lodz, Poland
}

Submitted: 14 January 2017

Accepted: 14 May 2017

Arch Med Sci 2019; 15 (3): 607-612

DOI: https://doi.org/10.5114/aoms.2017.68410

Copyright (c 2017 Termedia \& Banach

\begin{abstract}
Introduction: There are reports that diabetes mellitus reduces the risk of aortic aneurysms and many reports that diabetes mellitus reduces the risk of abdominal aortic aneurysms. In earlier years there were also studies that did not demonstrate any effects of diabetes on the rate of aortic aneurysms. Material and methods: For the year 2012, between 1 January and 31 December, reports for services regarding treatment for aortic aneurysms were found. At the same time, the reports for services associated with diabetes with the main diagnosis of "diabetes mellitus" were found in National Health Fund databases for 2012 with the special determinants.

Results: In Poland in 2012 the mean incidence of aortic aneurysms in both sexes in the group of subjects with diabetes calculated per 100,000 subjects with diabetes was $167.78 \pm 49.10$, and the mean incidence of aortic aneurysms in both sexes in the group of subjects without diabetes calculated per 100,000 of the general population after subtracting the number of subjects with diabetes was $27.72 \pm 9.40$. The incidence of aortic aneurysms among subjects with diabetes was significantly higher $(p<0.001)$ than the incidence of aortic aneurysms among subjects without diabetes.

Conclusions: Aortic aneurysms were more frequently observed in the group of patients with diabetes than in those without diabetes. Aortic aneurysms were observed three times more frequently in men than in women. In Poland in 2012, $27.20 \%$ of patients diagnosed with aortic aneurysms also had diabetes.
\end{abstract}

Key words: diabetes mellitus, incidence, aortic aneurysms.

\section{Introduction}

In the USA in 2009 aortic aneurysms were observed in 10,597 cases and were the leading cause of death [1, 2]. According to the Centers for Disease Control and Prevention (CDCP), the risk factors for aortic aneu-

\author{
Corresponding author: \\ Waldemar Wierzba MD, PhD \\ Department of Public Health \\ University of Humanities \\ and Economics \\ Lodz, Poland \\ Phone: +48 660196197 \\ E-mail:wwierzba@post.pl
}


rysms include arterial hypertension, hypercholesterolaemia, and tobacco smoking [3, 4]. There are reports that diabetes mellitus reduces the risk of aortic aneurysms [5] and many reports that diabetes mellitus reduces the risk of abdominal aortic aneurysms [6, 7]. In earlier years there were also studies that did not demonstrate any effects of diabetes on the rate of aortic aneurysms $[8,9]$.

As there are discrepancies with regard to the effects of diabetes on the incidence of aortic aneurysms in the global literature and there are no reports regarding this subject in Poland, an attempt of a pilot study in this field was made. Based on the data from the National Health Fund from the period 1 January to 31 December 2012 in Poland, this paper presents the incidence of aortic aneurysms in this period based on main diagnoses taken from hospitalisation reports in the population of patients diagnosed with and without diabetes.

\section{Material and methods}

Health services in Poland are financed by the National Health Fund (NHF) based on the act [10] and regulations of the Minister of Health that result from this act $[11,12]$. Health services in patients diagnosed with aortic aneurysm according to the following ICD-10 codes are performed as part of hospital treatment, namely under hospital contracts:

170.0 - dissecting aneurysm of any segment of the main aorta;

171.0 - dissecting aneurysm of the main aorta;

171.1 - aneurysm of the thoracic aorta, ruptured;

171.2 - aneurysm of the thoracic aorta, without rupture;

171.3 - aneurysm of the abdominal aorta, ruptured;

171.4 - aneurysm of the abdominal aorta, without rupture;

171.5 - aneurysm of the thoracoabdominal aorta, ruptured;

171.6 - aneurysm of the thoracoabdominal aorta, without rupture;

171.8 - aortic aneurysm of unspecified site, ruptured;

171.9 - aortic aneurysm of unspecified site, without rupture.

The regulations of the NHF president determine the organisation, financing and settlement of services [13, 14]. In 2008 homogeneous patient groups were introduced into the settlement system and since that time therapies have been funded in systems of special groups. Using Structured Query Language (SQL) in databases queries were performed in NHF databases in order to analyse such data presented in reports. The PESEL (personal ID no.) was considered to be a unique patient ID number [15].
For each year 2012, 2013 and 2014 between 1 January and 31 December reports for services regarding treatment for aortic aneurysms were found. At the same time, the reports for services associated with diabetes with the main diagnosis of "diabetes mellitus" were found in NHF databases for 2012 with the following determinants: E 10.X - insulin-dependent diabetes mellitus;

E 11.X - non-insulin-dependent diabetes mellitus; E 12.X - malnutrition-related diabetes mellitus;

E 13.X - other unspecified forms of diabetes mellitus;

E 14.X-unspecified diabetes mellitus or in this period a patient had a prescription for any medicinal products from the group A $10 . X$ (insulins), A 10 B.X (oral anti-diabetic agents) and specialist diagnostic tests. There were 2,227,453 such reports (PESEL numbers).

In 2012 a total of 13,794 patients were reported with the main diagnosis of aneurysm of the main aorta. The date of the first report for services mentioned above was determined arbitrarily for the year when an aortic aneurysm developed in a person with a given PESEL number.

\section{Statistical analysis}

Data were prepared with the statistical software of SAS and Statistica. Differences were considered to be significant at the significance level of $95 \%(p<0.05)$.

\section{Results}

Statistical data regarding the general incidence: 1 . In the period between 1 January and 31 December 2012 in total there were 2,227,453 patients with diabetes, 975,364 males and 1,252,089 females in the analysed Polish population.

2. The general population of Poland in 2012 was $38,533,784$ persons, including 18,651,441 males and 19,882,343 females, according to GUS (Main Statistical Office).

3. In 2012 the general population without diabetes included 36,309,331 persons: 17,676,077 males and 18,633,254 females.

Table I presents numbers of patients with the main diagnosis of aortic aneurysm in patients diagnosed with diabetes and without diabetes in whom the diagnosis was made in 2012.

In 2012 in Poland, in total 13,794 persons were diagnosed with the first diagnosis of aortic aneurysm. The mean age of women diagnosed with diabetes was significantly higher than the mean age of men $(p<0.01)$. The mean age of women and men without diabetes did not differ significantly. According to a comparison of the mean age of men in the group of patients with diabetes and the mean age of men in the group of patients 
Table I. Numbers of patients with the main diagnosis of aortic aneurysm in patients diagnosed with diabetes and without diabetes in whom the diagnosis was made in 2012

\begin{tabular}{|lccccc|}
\hline Patients & \multicolumn{2}{c}{ Men } & Women & $\begin{array}{c}\text { Men and women } \\
\text { together } \\
\text { Number }\end{array}$ \\
\cline { 2 - 5 } & Number & $\begin{array}{c}\text { Mean age } \pm \\
\text { standard deviation }\end{array}$ & Number & Mean age \pm & 3752 \\
With diabetes & 2906 & $69.63 \pm 9.32$ & 846 & $70.65 \pm 10.49$ & 10042 \\
\hline Without diabetes & 7710 & $65.83 \pm 12.51$ & 2332 & $66.05 \pm 14.20$ & \\
\hline
\end{tabular}

Table II. Percentages for all aortic aneurysms in 3 age groups in patients with and without diabetes in 2012

\begin{tabular}{|lcccccc|}
\hline Age & \multicolumn{3}{c}{ Patients with diabetes (\%) } & \multicolumn{2}{c|}{ Patients without diabetes (\%) } \\
\cline { 2 - 7 } & Men & Women & Together & Men & Women & Together \\
\hline Below the age of 44 & 0.71 & 1.86 & 1.04 & 5.63 & 8.10 & 6.34 \\
\hline Between 45 and 74 & 65.47 & 58.63 & 63.50 & 68.04 & 60.88 & 31.00 \\
\hline Above the age of 75 & 33.82 & 39.51 & 35.40 & 26.33 & 27.67 \\
\hline
\end{tabular}

without diabetes, men in the group with diabetes were significantly older $(p<0.001)$. Similarly, women in the group of patients with diabetes were significantly older than women in the group without diabetes $(p<0.001)$. The percentage of patients with diabetes diagnosed with aortic aneurysm in 2012 was $27.20 \%$, and the percentage of patients without diabetes diagnosed with aortic aneurysm was $72.80 \%$.

\section{Effect of age on incidence rate}

Table II lists percentage amounts for all aortic aneurysms in individual age groups in patients with and without diabetes in 2012 depending on the sex, based on the NHF data.

The highest rates of new cases of aortic aneurysms were observed in both men and women with and without diabetes aged between 45 and 74 years and they were in the range of $58.63 \%$ to $68.04 \%$. The lowest rates of new cases of aortic aneurysms were observed in the group below the age of 40 years inclusive. These rates did not differ significantly between men and women, and the total percent was $1.04 \%$ : $0.71 \%$ in men and $1.86 \%$ in women. In both sexes without diabetes below the age of 44 years the incidence was 6.34\%: $5.63 \%$ in men and $8.10 \%$ in women. The incidence of aortic aneurysms in subjects in this age group was many times higher in persons without diabetes compared to the incidence among diabetic patients.

Table III presents a comparison of percentage rates of men and women in 2012 with regard to subjects with and without diabetes according to the database of the NHF.

In male subjects with diabetes the percentage rate was $77.45 \%$, and in men without diabetes the rate was $76.78 \%$. On the other hand, the percent-
Table III. Percentages of men and women in 2012 in Poland with regard to subjects with and without diabetes

\begin{tabular}{|lcc|}
\hline Patients & Men (\%) & Women (\%) \\
\hline With diabetes & 77.45 & 22.55 \\
\hline Without diabetes & 76.78 & 23.22 \\
\hline
\end{tabular}

age rate of women among subjects with diabetes was $22.55 \%$, and in women without diabetes it was $23.22 \%$.

In 2012 the incidence of aortic aneurysms among both sexes was 37.72/100,000 of the general population, and in men it was 56.92/100,000 of the general population, whereas in women it was $15.98 / 100,000$ of the general population.

Table IV compares the incidence of aortic aneurysms in subjects with diabetes calculated per 100,000 subjects with diabetes and without diabetes calculated per 100,000 of the general population after subtracting the number of patients with diabetes reported in individual branches of the Voivodship National Health Fund in Poland in 2012.

In Poland in 2012 the mean incidence of aortic aneurysms in both sexes in the group of subjects with diabetes calculated per 100,000 subjects with diabetes was $167.78 \pm 49.10$, and the mean incidence of aortic aneurysms in both sexes in the group of subjects without diabetes calculated per 100,000 of the general population after subtracting the number of subjects with diabetes was $27.72 \pm 9.40$.

The incidence of aortic aneurysms among subjects with diabetes was significantly higher $(p<0.001)$ than the incidence of aortic aneurysms among subjects without diabetes.

Moreover, in the group of patients with diabetes the incidence of aortic aneurysms in 2012 in 
Table IV. Comparison of the incidence of aortic aneurysms in subjects with diabetes calculated per 100,000 subjects with diabetes and without diabetes calculated per 100,000 of the general population after subtracting the number of patients with diabetes reported in individual branches of the Voivodship National Health Fund in Poland in 2012

\begin{tabular}{|c|c|c|}
\hline Province & $\begin{array}{l}\text { Patients with aortic aneurysms } \\
\text { and diabetes mellitus per } 100,000 \\
\text { patients with diabetes }\end{array}$ & $\begin{array}{l}\text { Patients with aortic aneurysms } \\
\text { and without diabetes mellitus per } \\
100,000 \text { patients without diabetes }\end{array}$ \\
\hline Lower Silesia & 185.09 & 30.19 \\
\hline Kujawy-Pomerania & 211.77 & 29.84 \\
\hline Lublin & 141.04 & 51.55 \\
\hline Lubuskie & 71.61 & 12.31 \\
\hline Lodz & 197.81 & 23.25 \\
\hline Małopolska & 176.91 & 24.38 \\
\hline Mazovia & 225.29 & 34.55 \\
\hline Opole & 86.00 & 15.21 \\
\hline Podkarpacie & 189.32 & 22.68 \\
\hline Podlasie & 138.77 & 28.84 \\
\hline Pomerania & 135.93 & 19.59 \\
\hline Silesia & 184.67 & 27.31 \\
\hline Świętokrzyskie & 135.29 & 17.56 \\
\hline Warmia-Masuria & 205.08 & 32.99 \\
\hline Wielkopolska & 146.42 & 24.60 \\
\hline West Pomerania & 253.49 & 30.60 \\
\hline Poland (average \pm standard deviation) & $167.78 \pm 49.10$ & $27.22 \pm 9.40$ \\
\hline
\end{tabular}

various voivodships ranged between 71.61 and 253.49 calculated per 100,000 of patients with diabetes. The analysis presents the place where hospitalisation was reported and not the place of residence of patients.

\section{Discussion}

This analysis is unique and the first in Poland. It compares the incidence of aortic aneurysms in people without diabetes and with diabetes.

In Poland in 2012 we estimated the number of patients with diabetes on the basis of NHF data. This allowed us to calculate the incidence of aortic aneurysms in 100,000 patients with diabetes and to compare this figure with the occurrence of aortic aneurysms in those with no known diabetes in the 100,000 population of the general population after subtracting the number of patients with diabetes.

Controversies regarding the incidence of all types of aortic aneurysms may be a result of various methods to calculate the rate per 100,000 of the general population.

Lilienfeld et al. present the incidence of all types of aortic aneurysms. In men it was 40.6-
49.3/100,000 inhabitants. In women it was 6.8-12.3/100,000 inhabitants [16]. In 2012 in Poland the mean incidence of aortic aneurysms in subjects with diabetes was lower than the mean incidence of aortic aneurysms in subjects without diabetes in both sexes, men and women separately calculated per 100,000 of the general population.

However, if the second method of calculation is used, namely the number of new cases of aortic aneurysms in a given year in subjects with diabetes per 100,000 of subjects with diabetes and if the number of patients with aortic aneurysms in subjects without diabetes in a given year is calculated per 100,000 of the general population after subtracting the number of subjects with diabetes, the results obtained will be different.

When the incidence rates were calculated separately for all branches of the National Health Fund in Poland the incidence of aortic aneurysms in 2012 in subjects with diabetes of both sexes was $167.78 \pm 49.10$ on average per 100,000 of patients with diabetes, whereas the incidence of aortic aneurysms in 2012 in subjects without diabetes of both sexes was $27.22 \pm 9.40$ per 100,000 of the 
general population after subtracting the number of subjects diagnosed with diabetes.

In 2012 subjects with diabetes accounted for $27.2 \%$ of patients diagnosed with aneurysm of the main aorta. On the other hand, subjects without diabetes diagnosed with aortic aneurysms accounted for $72.8 \%$, namely $1 / 3$ of the number were patients with diabetes.

It has to be added that in 2012 in Poland the percentage of patients with diabetes in the whole national population was $5.78 \%$ [17]. Namely the subgroup of patients with diabetes was $1 / 17$ of the general population in 2012 in Poland. In our opinion the second method of calculation presents the incidence rates in the study populations more precisely compared to calculations per 100,000 of the general population. However, the problem is still open and further studies are required. Many reports regarding abdominal aorta aneurysms indicate that the incidence rate in subjects with diabetes is lower than in those without diabetes [18-21].

In the Spanish study diabetic patients accounted for $16.7 \%$ of all patients with abdominal aorta aneurysms [19]. Within the follow-up period of 10 years in Spain there was an increase of 33\% in the incidence of abdominal aorta aneurysms in the group of patients with diabetes, and in patients without diabetes this increase was $11 \%$.

Diabetic men were older by more than 4 years compared to our patients and accounted for $91.9 \%$ of all diabetic patients [19]. In our study $3 / 4$ of patients were men. In all reports aortic aneurysms are 2-6 times more frequently observed in men compared to women [6, 22, 23].

In our study the age of subjects with diabetes and aortic aneurysms was higher than the age of subjects with aortic aneurysms but without diabetes.

In our studies aortic aneurysms were observed the most frequently in the age group between 45 and 74 years, both in men and women, and in subjects with and without diabetes.

Aortic aneurysms were the least common in the age group from 44 years inclusive, in subjects with and without diabetes. In the age group below 44 years in subjects without diabetes aortic aneurysms developed a few times more frequently compared to their incidence in the same age group of diabetic patients.

Boll et al. stated that in men abdominal aorta aneurysms were observed at the age of 60-80 years [24]. Ashton et al. stated that abdominal aorta aneurysms were most frequently observed at the age of 65-74 years [25]. Bickerstaff et al. reported that the peak incidence of thoracic aorta aneurysms in men is at the age of 70 years, and in women the peak incidence of thoracic aorta aneurysms is at the age of approximately 80 years [26].
Our studies were limited by the fact that based on the data obtained it was not possible to determine precisely the type of diabetes, its duration, metabolic compensation of diabetes and complications. It was not possible to determine treatment reducing the LDL cholesterol levels precisely, and it was not possible to assess antihypertensive treatment.

In Poland there is no register of patients with diabetes. Therefore this paper attempts to evaluate the incidence of aortic aneurysms in subjects with and without diabetes.

In conclusion, the incidence of aortic aneurysms in Poland in 2012 calculated per 100,000 of the general population was as follows: 56.92 in men, 15.98 in women. Aortic aneurysms were more frequently observed in the group of patients with diabetes compared to those without diabetes. Aortic aneurysms were observed three times more frequently in men than in women. Aortic aneurysms were observed more frequently in men and women at the age between 45 and 74 years. In Poland in 2012, 27.20\% of patients diagnosed with aortic aneurysms also had diabetes.

\section{Conflict of interest}

The authors declare no concflict of interest.

\section{References}

1. Kochanek KD, XU J, Murphy SL, et al. Deaths: final data for 2009. Natl Vital Stat Rep 2011; 60: 1-116.

2. Go AS, Mozaffarian D, Roger VL, et al. Heart disease and stroke statistics - 2013 update: a report from the American Heart Association. Circulation 2013; 127: e6-e245.

3. Centres for disease control and prevention. Aortic aneurysm fact sheet /Data, Statistics/ HDSP/CDC. (http:// www.cdc.gov/dbdsp/data_statistics/fact_sheets/fs_ aortic_aneu), Accessed January 02, 2017.

4. Fleming C, Whitlock EP, Beil TL, Lederle FA. Screening for abdominal aortic aneurysm: a best-evidence systematic review for the U.S. Preventive services task force. Ann Intern Med 2005; 142: 203-11.

5. Gillum RF. Epidemiology of aortic aneurysm in the United States. J Clin Epidemiol 1995; 48: 1289-98.

6. Lederle FA, Johnson GR, Wilson SE, et al. Prevalence and associations of abdominal aortic aneurysm detected through screening. Aneurysm Detection and Management (ADAM) Veterans Affairs Cooperative Study Group. Ann Intern Med 1997; 126: 441-9.

7. De Rango P, Farchioni L, Fiorucci B, Lenti M. Diabetes and abdominal aortic aneurysm. Eur J Vasc Endovasc Surg 2014; 47: 243-61.

8. Strachan DP. Predictors of death from aortic aneurysm among middle-aged men: the Whitehall Study. Br J Surg 1991; 78: 401-4.

9. Reed D, Reed C, Stemmermann G, Hayashi T. Are aortic aneurysm caused by atherosclerosis? Circulation 1992; 85: 205-11.

10. Ustawa z dnia 27.08.2008 roku o Świadczeniach Opieki Zdrowotnej finansowanych ze środków publicznych (Dz. U. 2008. nr 164 poz. 1027 z późn. zm) [Polish]. 
11. Rozporzązenie Ministra Zdrowia z dnia 11.01.2010 roku zmieniające rozporządzenie w sprawie świadczeń gwarantowanych z zakresu programów zdrowotnych (Dz. U. 2010 nr 05 poz. 29 z późn. zm.) [Polish].

12. Rozporządzenie Ministra Zdrowia z dnia 02.03.2010 roku zmieniające rozporządzenie $w$ sprawie świadczeń gwarantowanych z zakresu leczenia szpitalnego (Dz. U. $2010 \mathrm{nr} 30$ poz. 157 z późn. zm.) [Polish].

13. Zarządzenie Nr 101/2007/ DGL Prezesa Narodowego Funduszu Zdrowia z dnia 5 listopada 2007 roku zmieniające zarządzenia w sprawie przyjęcia szczegółowych materiałów informacyjnych $w$ przedmiocie postępowania w sprawie zawarcia umów o udzielaniu świadczeń opieki zdrowotnej oraz o realizacji i finasowania umów o udzielanie świadczeń opieki zdrowotnej w rodzaju: leczenie szpitalne. [Polish].

14. Zarządzenie nr 36 /2008/ DGL Prezesa Narodowego Funduszu Zdrowia z dnia 19 czerwca 2008 roku w sprawie określenia warunków zawierania i realizacji umów w rodzaju leczenie szpitalne w zakresie terapeutyczne problemy zdrowotne. [Polish].

15. PESEL. http://www.msw.gov.pl/portal/pl/381/32/PESEL. html. Accessed January 22, 2007 [Polish].

16. Lilienfeld DE, Baxter J, Sprafka JM. Prevalence of aortic aneurysm in the Twin Cities metropolitan area, 197984. Public Health Rep 1993; 108: 506-10.

17. Czeleko T, Śliwczyński A, Dziemidok P, Karnafel W. Cukrzyca znana w 2012 roku. Ocena chorobowości na podstawie danych Narodowego Funduszu Zdrowia (NFZ) w Polsce - w środowisku miejskim i wiejskim [Polish]. Med Metabol 2017; 21: 16-23.

18. Eckstein HH, Bockler D, Flessenkamper I, et al. Ultrasonographic screening for the delection of abdomina aortic aneurysm. Dtsch Arztebl Int 2009; 106: 657-63.

19. Lopez-de-Andres A, Jimenez-Trujillo I, Jimenez-Garcia R, et al. National trends in incidence and outcomes of abdominal aortic aneurysm among elderly type 2 diabetic and non-diabetic patients in Spain (2003-2012). Cardiovasc Diabetol 2015; 14: 2-12.

20. Kent KC, Zwolak RM, Egorova NN, et al. Analysis of risk factors of abdominal aortic aneurysm in a cohort of more than 3 million individuals. J Vasc Surg 2010; 52: 539-48.

21. Shah AD, Langenberg C, Rapsomaniki E, et al. Type 2 diabetes and incidence of cardiovascular diseases: a cohort study in 1.9 milion people. Lancet Diabetes Endocrinol 2015; 3: 105-13.

22. Rodin MB, Daviglus ML, Wong GC, et al. Middle age cardiovascular risk factors and abdominal aortic aneurysm in older age. Hypertension 2003; 42: 61-8.

23. Singh K, Bonaa KH, Jacobsen BK, et al. Prevalence of and risk factors for abdominal aortic aneurysm in a population-based study: the Tromso Study. Am J Epidemiol 2001; 154: 236-44.

24. Boll AP, Verbeek AL, van de Lisdonk EH, et al. High prevalence of abdominal aortic aneurysm in a primary care screening programme. Br J Surg 1998; 85: 1090-4.

25. Ashton HA, Buxton MJ, Day NE, et al. The Multicentre Anurysm Screening Study (MASS) into the effect of abdominal aortic aneurysm screening on mortality in men: a randomised controlled trial. Lancet 2002; 360: 1531-9.

26. Bickerstaff LK, Pairolero PC, Hollier LH, et al. Thoracic aortic aneurysm: a population-based study. Surgery 1982; 92: 1103-8. 